\title{
Editorial:
}

\section{LiDAR - rapid developments in remote sensing of geological features}

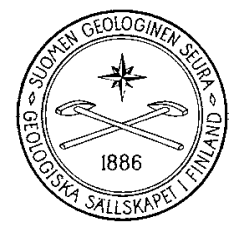

\author{
Antti E.K. Ojala ${ }^{I}$ and Pertti Sarala ${ }^{2}$ \\ ${ }^{1}$ Geological Survey of Finland, P.O. Box 96, FI-02151, Espoo, Finland \\ ${ }^{2}$ Geological Survey of Finland, P.O. Box 77, FI-96101, Rovaniemi, Finland
}

LiDAR-based (Light Detection And Ranging) 2 m-grid digital elevation models (DEM) are exceptional remote sensing data in geosciences in many aspects: they can be used to constrain terrain features in greater detail than ever before (Johnson et al., 2015), allow extraction of new geomorphological features and relationships (Mäkinen et al., 2017), provide a possibility of acquiring $3 \mathrm{D}$ information of the terrain, and nowadays cover extensive areas in Finland (ca. 90\%), and elsewhere in the Fennoscandian Shield. LiDAR DEMs open up new ways of investigating and modelling of geological processes and geomorphological characteristics, and thus provide significant potential for advancing theories in geosciences.

In Scandinavia, high-resolution LiDAR imagery has so far been employed to study and map a wide range of glacial geomorphology and postglacial terrain features. These include research on issues such as ribbed (Rogen) and hummock moraines and their tracks and corridors (Möller and Dowling, 2015; Peterson et al., 2017), ice streaming (Greenwood et al., 2015), De Geer moraines (Bouvier et al., 2015; Ojala et al., 2015; Ojala 2016), subglacial meltwater systems (Sarala et al., 2015), beach ridges, cliffs and shore terraces (Ojala et al., 2013), fluvial terraces, floods plains and lateral meltwater channels (Eilertsen et al., 2015), postglacial fault scarps and landslides (e.g. Mikko et al., 2015; Palmu et al., 2015; Ojala et al., 2017a, $2017 \mathrm{~b}$ ), as well as bedrock lineaments, fracture sets, and fissures (Scheiber et al., 2015; Skyttä et al., 2015).

The present thematic issue is a follow up of the "Unraveling Scandinavian Geomorphology: the LiDAR revolution" Special Issue published in the GFF in 2015 (Johnson et al., 2015). Here, we concentrate on LiDAR-based applications in mapping of glacial deposits and glaciodynamic features in Finland, a project that was launched by the Geological Survey of Finland in 2015 (Putkinen et al., 2016). The first paper by Putkinen et al. (2017) shows how the availability of LiDAR DEMs has fundamentally changed the process of mapping Quaternary deposits in Finland. They introduce the new national Glacier Dynamic database (GDdatabase) focusing on recording superficial deposits and features created by continental glaciers in Finland during the last ice ages. In their article and supplementary files, Putkinen et al. (2017) also illustrate tens of representative examples of different geological features mapped for the GDdatabase. Furthermore, they provide examples of site-specific mapping procedures and applications of the stored information in understanding of dynamic ice stream lobes during glaciation. 
In the second paper by Sarala and Räisänen (2017), the focus is on glacial lineations (about 9000 individual features) and interpretation of ice lobe evolution based on streamlined erosional and depositional formations, hummocky and ribbed moraines and glaciofluvial formations in the area of eastern Kuusamo Ice Lobe, northern Finland. New results reveal that modern superficial deposits were formed during three different ice flow phases of the Weichselian glaciations. Based on LiDAR data analysis, different erosional and depositional formation patterns can be separated to evaluate ice flow phases, subglacial conditions and mass balance of the ice lobe during its life cycle. The length of lineations also indicates variation in glacier flow velocities and transport distances.

In the third paper by Nikarmaa et al. (2017) authors examine the behaviour and subglacial conditions of the North Karelian/Oulu Ice Lobe with the inversion modelling method. The method is based on the identification and interpretation of mapped glacigenic streamlined lineations that were formed during active ice flow stages. Results indicate that the ice lobe dynamics were strongly affected by pre-existing Quaternary

\section{References}

Bouvier, V., Johnson, M. \& Påsse, T., 2015. Distribution, genesis, and annual-origin of De Geer moraines in Sweden: insights revealed by LiDAR. GFF 137, 119-333. https://doi.org/10.1080/11035897.2015.1089933

Greenwood, S.L., Clason, C.C., Mikko, H., Nyberg, J., Peterson, G. \& Smith, C.A., 2015. Integrated use of LiDAR and multibeam bathymetry reveals onset of ice streaming in the northern Bothnian Sea. GFF 137, 284292. https://doi.org/10.1080/11035897.2015.1055513

Eilertsen, R.S., Corner, S.D. \& Hansen, L., 2015. Using LiDAR data to characterize and distinguish among different types of raised terraces in a fjord-valley setting. GFF 137, 353-361. https://doi.org/10.1080/11035897.2015.1111409

Johnson, M., Fredin, O., Ojala, A.E.K. \& Peterson, G., 2015. Unraveling Scandinavian geomorphology: The LiDAR revolution. GFF 137, 245-251. https://doi.org/10.1080/11035897.2015.1111410 sediment thickness, bedrock lithology, structures and topography. These features caused ice mass movement through flow corridor pattern with several retreat and re-advance cycles throughout the North Karelian/Oulu Ice Lobe life span.

We hope that this Special Issue will provide readers new ideas and motivation to apply LiDAR data, not only in geomorphological mapping, but also in advanced analysis of the relationship between different superficial geological features, their formation processes, and understanding of the development of the land systems in glaciated terrains. The Geological Society of Finland and the Geological Survey of Finland are thanked for their support during the editorial process and publishing this special issue. Furthermore, eight volunteer international experts are thanked for their kind help in reviewing the manuscripts and providing valuable comments and suggestions that improved the quality of published articles. All scientists and institutes that helped with this Special Issue are also acknowledged.

In Espoo and Rovaniemi on 27 $7^{\text {th }}$ September 2017 Antti E.K. Ojala and Pertti Sarala
Mikko, H., Smith, C.A., Lund, B., Ask, M.V.S. \& Munier, R., 2015. LiDAR-derived inventory of post-glacial fault scarps in Sweden. GFF 137, 334-338. https://doi.org/10.1080/11035897.2015.1036360

Mäkinen, J., Kajuutti, K., Palmu, J.-P., Ojala, A. \& Ahokangas, E., 2017. Triangular-shaped Landforms Reveal Subglacial Drainage Routes in SW Finland. Quaternary Science Reviews 164, 37-53. https://doi.org/10.1016/j.quascirev.2017.03.024

Möller, P \& Dowling, D.P.F., 2015. The importance of thermal boundary transitions on glacial geomorphology; mapping of ribbed/hummocky moraine and streamlined terrain from LiDAR, over Småland, South Sweden. GFF 137, 252-284. https://doi.org/10.1080/11035897.2015.1051736

Nikarmaa T., Lunkka, J.P. \& Putkinen N., 2017. Factors affecting the dynamics of the North Karelian/Oulu Ice Lobe, Central Finland, during the last deglaciation - a LiDAR and DEM interpretation of subglacial lineation 
patterns. Bulletin of the Geological Society of Finland, this volume

Ojala, A.E.K., 2016. Appearance of De Geer moraines in southern and western Finland - implications for reconstructing glacier retreat dynamics. Geomorphology $255,16-25$. https://doi.org/10.1016/j.geomorph.2015.12.005

Ojala, A.E.K., Palmu, J.-P, Åberg, A., Åberg, S. \& Virkki, H., 2013. Development of an ancient shoreline database to reconstruct the Litorina Sea maximum extension and the highest shoreline of the Baltic Sea basin in Finland. Bulletin of the Geological Society of Finland 85, 127-144. https://doi.org/10.17741/bgsf/85.2.002

Ojala, A.E.K., Putkinen, N., Palmu, J.-P. \& Nenonen, K., 2015. Characterization of De Geer moraines in Finland based on LiDAR DEM Mapping. GFF 137, 304-318. https://doi.org/10.1080/11035897.2015.1050449

Ojala, A.E.K., Mattila, J., Ruskeeniemi, T., Palmu, J.-P., Lindberg, A., Hänninen, P. \& Sutinen, R., 2017. Postglacial seismic activity along the IsovaaraRiikonkumpu fault complex. Global and Planetary Change 157, 59-72. https://doi.org/10.1016/j.gloplacha.2017.08.015

Ojala, A.E.K., Mattila, J., Markovaara-Koivisto, M., Ruskeeniemi, T., Palmu, J.-P., Sutinen, R., 2017. Distribution and morphology of landslides in northern Finland - analysis of postglacial seismic activity. Geomorphology, in press. https://doi.org/10.1016/j.geomorph.2017.08.045

Palmu, J.-P., Ojala, A.E.K., Ruskeeniemi, T., Sutinen, R. \& Mattila, J. 2015. LiDAR DEM detection and classification of postglacial faults and seismically-induced landforms in Finland: a paleoseismic database. GFF 137, 344-352. https://doi.org/10.1080/11035897.2015.1068370

Peterson, G., Johnson, M.D. \& Smith, C.A. 2017. Glacial geomorphology of the south Swedish uplands - focus on the spatial distribution of hummock tracts.
Journal of maps 13, 534-544.

https://doi.org/10.1080/17445647.2017.1336121

Putkinen, N., Eyles, N., Putkinen, S., Ojala, A.E.K., Palmu, J.-P., Sarala, P., Väänänen, T., Räisänen, J., Saarelainen, J., Ahtonen, N., Rönty, H., Kiiskinen, A., Rauhaniemi, T. \& Tervo, T. 2017. High-resolution LiDAR mapping of ice stream lobes in Finland. Bulletin of the Geological Society of Finland, this volume

Putkinen, S., Putkinen, N., Sarala, P., Palmu, J.-P., Ojala, A. \& Ahtonen, N. 2016. Map database of superficial deposits and glaciodynamic features in Finland - methodology and classifications. In: Staboulis, S., Karvonen, T. \& Kujanpää, A. (eds.), Abstracts of the 32nd Nordic Geological Winter Meeting, 13th-15th January 2016, Helsinki, Finland. Bulletin of the Geological Society of Finland, Special Volume, pp. 310.

Sarala, P., Räisänen, J., Johansson, P. \& Eskola, K.O. 2015. Aerial LiDAR analysis in geomorphological mapping and geochronological determination of surficial deposits in the Sodankylä region, northern Finland. GFF 137:4, 293-303. https://doi.org/10.1080/11035897.2015.1100213

Sarala, P. \& Räisänen J. 2017. Evolution of the eastern part of the Kuusamo Ice Lobe, based on geomorphological interpretation of high-resolution LiDAR data. Bulletin of the Geological Society of Finland, this volume

Scheiber, T., Fredin, O., Viola, G., Jarna, A., Gasser, D. \& Łapińska-Viola, R. 2015. Manual extraction of bedrock lineaments from high-resolution LiDAR data: methodological bias and human perception. GFF 137, 362-372. https://doi.org/10.1080/11035897.2015.1085434

Skyttä, P., Kinnunen, J., Palmu, J.-P. \& Korkka-Niemi, K. 2015. Bedrock structures controlling the spatial occurrence and geometry of $1.8 \mathrm{Ga}$ younger glacifluvial deposits - Example from First Salpausselkä, southern Finland. Global and Planetary Change 135, 66-82. https://doi.org/10.1016/j.gloplacha.2015.10.007 